\section{PENINGKATAN JALAN PADA AREAL PERTANIAN GUNA MENINGKATKAN PEREKONOMIAN MASYARAKAT DI DESA DONOWARIH KECAMATAN KARANGPLOSO}

\author{
Ir. .Alik Ansyori Alamsyah, $\mathrm{MT}^{1}$ )
}

\section{Ringkasan}

Desa Donowarih Kecamatan Karangploso merupakan daerah yang terletak disebelah Barat dari Kecamatan Karangploso dengan penduduk yang berjumlah sekitar 7.206 jiwa merupaka salah satu Desa yang mempunyai penduduk terpadat di kawasan Karangploso. Desa Donowarih terbagi menjadi 5 pedukuhan dimana penduduk mayoritasnya mempunyai mata pencaharian petani dan berpendidikan mayoritas setingkat Sekolah Menengah Pertama.

Mata pencaharian sebagai petani jelas lahan pertanian merupakan gantungan hidup bag warga Desa Donowarih tersebut. Kondisi ini sangat mempengaruhi daya beli masyarakat. Lahan pertanian masyarakat Desa Donowarih 75 \% merupakan lahan sawah dan merupakan sentra pertanian sayur di Kecamatan Karangploso. Selama ini masyarakat Desa Donowarih pada saa melakukan panen sangat terkendala sarana prasarana karena itu hasil pertanian yang ada kurang begitu optimal dalam mendongkrak pendapatan bagi warga Desa Donowarih. Hal ini terjad karena hasil panen masih terpotong oleh pengeluaran - pengeluaran pasca panen berupa pemasarannya.

Akses yang ada untuk menuju lahan pertanian selama ini hanya berupa jalan setapak. Hal ini tentu sangat berdampak terhadap petani sayur di Desa Donowarih. Beberapa upaya sudah dilakukan oleh perangkat desa beserta masyarakat untuk memperbaiki akses menuju areal pertanian, tetapi selalu terkendala banyak faktor. Melihat kondisi tersebut, perlu dilaksanakan pembangunan infra struktur berupa pembangunan/peningkatan jalan makadam. Dalam pengabdian ini telah terlaksana/pembangunan dan peningkatan dengan panjang sekitar 1000 meter. Kedepan seiring dengan permintaan masyarakat Desa Donowarih perlu ditingkatkan lagi dengan jalan lapis penetrasi.

Pembangunan sarana dan prasarana jalan desa/kampung menentukan peningkatan kegiatan ekonomi masyarakat, untuk itu diperlukan program keberlanjutan yang melibatkan pemerintah daerah, perguruan tinggi, dan masyarakat untuk melaksanakan pembangunan dan perawatan jalan di desa/kampung.

${ }^{1}$ )Staf Pengajar Fakultas Teknik UMM

Jurnal Dedikasi Volume. 8, Mei 2011

\section{A. Pendahuluan}

\section{Analisis Situasi}

Desa Donowarih Kecamatan Karangploso merupakan daerah yang terletak disebelah Barat dari Kecamatan Karangploso, dengan penduduk yang berjumlah sekitar 7.206 jiwa merupakan salah sat Desa yang mempunyai penduduk terpadat di kawasan Karangploso. Desa Donowarih terbagi menjadi 5 pedukuhan dimana penduduk mayoritasnya bermata pencaharian petani dan berpendidikan mayoritas setingkat Sekolah Menengah Pertama.

Mata pencaharian sebagian besar petani, lahan pertanian merupakan gantungan hidup bagi warg Desa Donowarih tersebut. Kondisi ini sangat mempengaruhi daya beli masyarakat. Lahan pertanian masyarakat Desa Donowarih 75\% merupakan lahan sawah dan merupakan sentra pertanian sayur di Kecamatan Karangploso.

Selama ini masyarakat Desa Donowarih pad saat melakukan panen sangat terkendala saran prasarana karena itu hasil pertanian yang ada kurang begitu optimal dalam mendongkrak pendapatan bag warga Desa Donowarih. Hal ini terjadi karena hasi panen masih terpotong oleh pengeluaran pengeluaran pasca panen berupa pemasaran.

Akses yang ada untuk menuju lahan pertania selama ini hanya berupa jalan setapak. Hal ini sanga berdampak terhadap petani sayur di Desa Donowarih. Beberapa upaya sudah dilakukan oleh perangkat desa beserta masyarakat untuk memperbaiki akses menuju areal pertanian, tetapi selalu terkendala banyak faktor.

Melihat kondisi itu perlu kiranya dilakukan suatu program pendampingan untuk mewujudkan angan angan atau obsesi masyarakat Desa Donowarih untuk mempunyai akses jalan menuju areal pertanian yang selama ini sulit terwujud tersebut. Tujuan program pendampingan ini adalah bagaimana memotivasi masyarakat untuk tergugah membangun jalan yang biasa dilewati oleh kendaraan bermotor roda 4 , sehingga bisa mengurangi pengeluaran pada saat panen dan meningkatkan pendapatan masyarak Desa Donowarih Kecamatan Karangploso.

\section{B. Tinjauan Pustaka}

1. Perkembangan Teknologi Jalan Raya

Sejarah perkembangan jalan raya dimulai dengan sejarah manusia itu sendiri yang selalu berhasrat untuk mencari kebutuhan hidup dan berkomunikasi dengan sesama, dengan demikian perkembangan jalan saling berkaitan dengan teknik jalan, seiring dengan perkembangan teknologi yang ditemukan manusia.

Pada awalnya jalan raya hanya berupa jejak manusia yang mencari kebutuhan hidup. Setelah manusia mulai hidup berkelompok jejak - jejak berubah menjadi jalan setapak yang masih belum berbentuk jalan yang rata, maka dipergunakan alat transportasi seperti hewan, kereta, atau yang lainnya mulai dibuat jalan yang rata.

Sejarah perkembangan jalan di Indonesia yang tercatat dalam sejarah bangsa Indonesia adalah pembangunan jalan Daendles pada jaman Belanda, yang dibangun dari Anyer di Banten sampai Panarukan di Banyuwangi Jawa Timur. Yang diperkirakan panjangnya 1000 kilometer. pada akhir abad 18 . Tujuan pembangunan pada saat itu terutama untuk kepentingan strategis dan dimasa tanam paksa untuk memudahkan pengangkutan hasil bumi

Jalan Daendles tersebut belum direncanakan secara teknis baik geometrik maupun perkerasannya. Konstruksi perkerasan jalan berkembang pesat pada jaman keemasan Romawi. Pada saat itu telah mula dibangun jalan jalan - jalan yang terdiri dari beberapa lapis perkerasan. Perkembangan konstruksi perkerasan jalan seakan terhenti dengan runtuhnya kekuasaan Romawi sampai abad 18

Pada abad 18 para ahli dari Perancis, Skotlandia menemukan bentuk perkerasan yang sebagian sampai sekarang umum digunakan di Indonesia dan merupakan awal dari perkembangan konstruksi perkerasan di Indonesia yang antara lain : Konstruksi batu belah ( Telford ), Konstruksi perkerasan Mac Adam.

Konstruksi Telford diciptakan oleh Thomas Telford ( 1757 - 1834 ) dari Skotlandia, sedangkan 
Mac Adam oleh Jhon London Mac Adam ( 1756 - keamanan, kenyamanan dan daya dukung dari 1836) dari Skotlandia.

Perkerasan jalan yang menggunakan aspal sebagai bahan pengikat ditemukan pertama kali di Babylon pada tahun 625 SM, tetapi perkerasan jenis ini tidak berkembang sampai ditemukan kendaraan bermotor oleh Gofflieb Daimler dan Karl Benz pada tahun 1880. Mulai tahun 1920 sampai sekarang teknologi konstruksi perkerasan dengan menggunakan aspal sebagai bahan pengikat maju pesat. Di Indonesia perkembangan perkerasan aspal dimulai pada tahap awal berupa konstruksi Telford dan Mac Adam yang kemudian diberi lapisan aus yang menggunakan aspal sebagai bahan pengikat dan ditaburi pasir kasar yang kemudian berkembang menjadi lapisan penetrasi ( lapisan Burtu, Burda, Buras ). Tahun 1980 diperkenalkan perkerasan jalan dengan aspal emulsi dan Butas, tetapi dalam pelaksanaan dan pemakaian aspal butas terdapat permasalahan dalam hal variasi kadar aspalnya yang kemudian disempurnakan pada tahun 1990 dengan teknologi beton mastic, perkembangan konstruksi perkerasan jalan menggunakan aspal panas ( hot mix mulai berkembang di Indonesia pada tahy 1975, kemudian disusul dengan jenis yang lain seperti aspal beton (AC) dan lain - lain.

Konstruksi perkerasan menggunakan semen
Kato bagai bahan pengikat telah ditemukan pada tahun 1928 di London tetapi konstruksi perkerasan ini mulai berkembang pesat sejak tahun 1970 dimana mulai diperkenalkannya pembangunan perkerasan jalan sesuai dengan fungsinya, sedangkan perencanaan geometrik jalan seperti sekarang ini baru dikenal sekitar pertengahan tahun 1960 kemudian mengalami perkembangan yang cukup pesat sejak tahun 1980

\section{Klasifikasi dan Fungsi Jalan}

Perkembangan angkutan darat, terutama kendaraan bermotor yang meliputi jenis ukuran dan jumlah maka masalah kelancaran arus lalu lintas, perkerasan jalan harus menjadi perhatian, oleh karena u perlu pembatasan - pembatasan.

Menurut Peraturan Pemerintah No. 26 jalan jan dilingkungan perkotaan terbagi dalam jaringan jalan primer dan jaringan jalan sekunder. Jalan - jalan sekunder dimaksud untuk memberikan pelayanan kepada lalu lintas dalam kota, oleh karena itu perencanaan dari jalan - jalan sekunder hendaknya disesuaikan dengan rencana induk tata ruang kota yang bersangkutan. Dari sudut lain, seluruh jalan perkotaan mempunyai kesamaan dalam satu hal, yait kurangnya lahan untuk pengembangan jalan tersebut. Dampak terhadap lingkungan disekitarnya harus diperhatikan dan diingat bahwa jalan itu sendiri - taman perkotaan.

\subsection{Berdasarkan Sistem Jaringan Jalan}

a. Sistem Jaringan Jalan Prime

Sistem jaringan jalan primer disusun mengikuti ketentuan pengaturan tata ruang dan struktur pengembangan wilayah tingkat Nasional, yang menghubungkan simpul simpul jasa distribusi. Jaringan jalan prime menghubungkan secara terus-menerus kota jenjang ke satu, kota jenjang ke dua, kota jenjang ke tiga, dan kota - kota dibawahnya sampai ke persil dalam satuan wilayah pengembangan. Jaringan jalan primer menghubungkan kota jenjang ke satu dengan kota jenjang ke satu antar satuan wilayah pengembangan. Jaringan jalan primer tidak terputus walaupun memasuki kota, jaringan jalan primer harus menghubungkan kawasan primer. Suatu ruas jalan primer dapat berakhir pada suatu kawasan primer. Kawasan yang mempunyai fungsi primer antara lain : industr berskala regional, bandar udara, pasar induk, pusat perdagangan skala regional/grosir.

b. Sistem Jaringan Jalan Sekunder

Sistem jaringan jalan sekunder disusun mengikuti ketentuan pengaturan tata ruan kota yang menghubungkan kawasan kawasan yang memiliki fungsi primer, fungsi sekunder kesatu, fungsi sekunder kedua, melayani berbagai kepentingan umum seperti taman fungsi sekunder ketiga dan seterusnya sampai ke perumahan.

2.2. Berdasarkan Fungsinya

a.Jalan Arteri Primer, adalah jalan yang menghubungkan kota jenjang kesatu dengan kota jenjang kedua.

Untuk jalan arteri primer wilayah perkotaan, mengikuti kriteria sebagai berikut:

1. Jalan arteri primer dalam kota merupakan terusan arteri primer luar kota

2. Jalan arteri primer melalui atau menuju kawasan primer

3. Jalan arteri primer dirancang berdasarkan kecepatan paling rendah $60 \mathrm{~km} / \mathrm{jam}$

4. Lebar badan jalan tidak kurang dari 8 mete

5. Lalu lintas jarak jauh pada jalan arteri prime adalah lalu lintas regional. Untuk itu, lalu lintas tersebut tidak boleh terganggu oleh lalu lintas ulang alik dan lalu lintas lokal, dan kegiatan lokal

6. Kendaraan angkutan berat dan kendaraan umum bus dapat diijinkan menggunakan jalan ini

b. Jalan Kolektor Primer, adalah jalan yang menghubungkan kota jenjang kedua dengan kota jenjang kedua atau menghubungkan kota jenjang kedua dengan kota jenjang ketiga.

Untuk wilayah perkotaan kriterianya :

1. Jalan kolektor primer kota merupakan terusan jalan kolektor primer luar kota

2. Melalui atau menuju kawasan primer atau jalan arteri primer

3. Dirancang untuk kecepatan $40 \mathrm{~km} / \mathrm{jam}$

4. Lebar badan jalan tidak kurang dari 7 meter

5. Jumlah jalan masuk dibatasi secara efisien dan jarak antaranya lebih dari 400 meter

6. Kendaraan angkuta berat dan bus dapat diijinkan melalui jalan in

c. Jalan Lokal Primer, adalah jalan yang menghubungkan kota jenjang kesatu dengan persiil atau menghubungkan kota jenjang kedua dengan persiil atau kota jenjang ketig dengan kota jenjang ketiga, kota jenjang ketiga dengan kota dibawahnya, atau kota jenjang ketiga dengan persiil atau kota dibawah jenjang ketiga sampai persiil.

Kriteria untuk jalan lokal primer :

1. Merupakan terusan jalan lokal primer luar kota

2. Melalui atau menuju kawasan primer atau jalan primer lainnya

3. Dirancang untuk kecepatan $20 \mathrm{~km} / \mathrm{jam}$

4. Kendaraan angkutan barang dan bus diijinkan melaluijalan ini

5. Lebar jalan tidak kurang dari 6 meter

6. Besarnya LHR pada umumnya paling rendah pada sistem primer. Kawasan primer adalah kawasan kota yang mempunyai fungsi primer. Fungsi primer adalah fungsi kota dalam hubungannya dengan kedudukan kota sebagai pelayanan jasa bagi kebutuhan pelayanan kota, dan wilayah pengembangannya.

d. Jalan Arteri Sekunder, menghubungkan kawasan primer dengan kawasan sekunder kesatu atau menghubungkan kawasan kesatu dengan kawasan sekunder kedua.

Kriteria untuk jalan perkotaan :

1. Dirancang berdasarkan kecepatan paling rendah $20 \mathrm{~km} / \mathrm{jam}$

2. Lebar badan jalan tidak kurang dari 7 meter

3. Kendaraan angkutan barang berat tidak diijinkan melalui jalan ini didaerah pemukiman

4. Besarnya LHR pada umumnya lebih rendah dari sistem primer

5. Harus mempunyai perlengkapan jalan yang cukup.

e. Jalan Lokal Sekunder, menghubungkan antar kawasan sekunder ketiga atau dibawahnya dan kawasan sekunder dengan perumahan.

Kriteria untuk daerah perkotaan adalah :

1. Dirancang berdasarkan kecepatan paling rendah $10 \mathrm{~km} / \mathrm{jam}$

2. Lebar badan jalan tidak kurang dari 5 meter

3. Kendaraan angkutan barang dan bus tidak diijinkan melalui jalan ini didaerah pemukiman. 
Jalan Kerikil

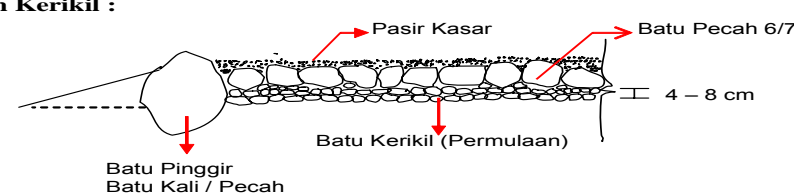

Batu Pinggir
Batu Kali / Pecah

Jalan Telford

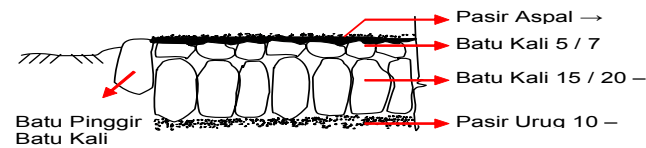

Batu Pinggir
Batu Kali
$10 / 15-15$

Jalan Makadam :
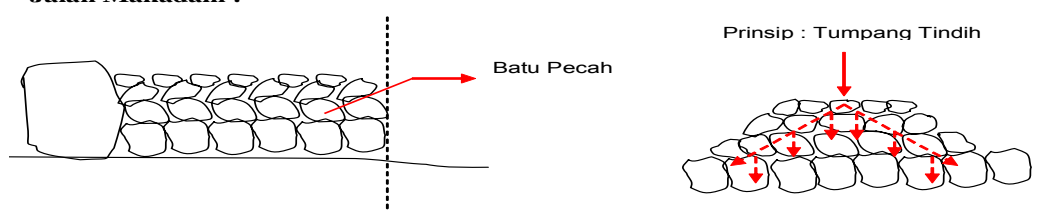

\section{Jalan Lapis Penetrasi :}

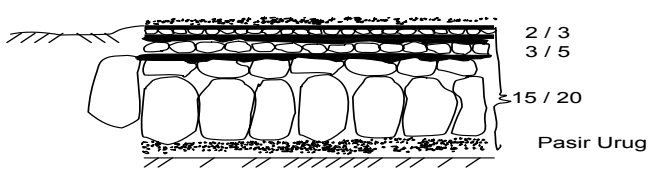

Jalan Butas :

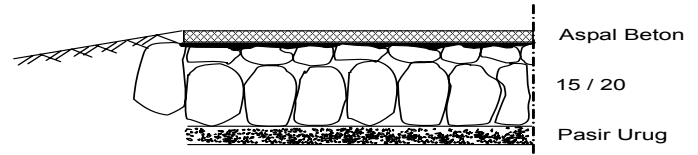

Jalan Lapis Aspal Beton :

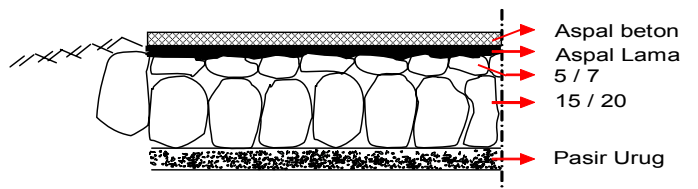

Prinsip : Desak

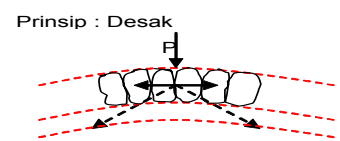

Alik Ansyori Alamsyah. Peningkatan Jalan Pada Areal Pertanian Di Desa Donowarih Kecamatan Karangploso

\section{Materi dan Metode}

1. Waktu dan Tempat

Kegiatan ini dilaksanakan pada warga Des Donowarih Kecamatan Karangploso yang pelaksanaannya dilakukan pada bulan Oktober 2010 sampai bulan Juli 2011

\section{Khalayak Sasaran}

Dalam kegiatan ini khalayak sasaran yan dianggap strategis untuk mencapai tujuan yan diharapkan adalah seluruh komponen yang ada di Desa Donowarih Kecamatan Karangploso. Sehingga diharapkan tujuan yang dicapai pada akhirnya tidak secara parsial saja, tetapi menyeluruh. Dengan emikian garap disesuaikan dengan rencana penggunaanya, yakni seluruh warga Desa Donowarih Kecamata Karangploso.

3. Metode Kegiatan

Metode kegiatan pengabdian ini meliputi :

Observasi lapang, wawancara, pelatihan, dan pembenahan jalan makadam. Sedangkan kegiatan pengabdian masyarakat ini ada beberapa tahapan kegiatan yang didiskripsikan sebagai berikut :

Memotivasi kesadaran pentingnya aksesibilitas yang tinggi.

Merealisasikan pembuatan jalan manuju areal pertanian.

Melakukan pendampingan pasca pembangunan jalan ( perawatan jalan )

\section{Hasil dan Pembahasan}

\section{Hasil Kegiatan}

Berdasarkan hasil pengumpulan data, dan pengolahan data yang meliputi observasi dan tatap muka secara langsung dalam bentuk sharing dengan semua masyarakat Desa Donowarih, ternyat mayoritas penduduk Desa Donowarih sangat berharap adanya perubahan di Desanya yang berkaitan dengan masalah pembangunan jalan di areal lahan pertanian. Kegiatan sosialisasi yang telah dilakukan secara terstruktur tersebut menunjukkan adanya kekurang harmonisan antara masyarakat dengan perangkat Desa Donowarih Kecamatan Karangploso.

lik Ansyori Alamsyah.Peningkatan Jalan Pada Areal Pertanian Guna Meningkatkan Perekonomian Masyarakat

Di Desa Donowarih Kecamatan Karangploso
Sosialisasi dan sharing dengan masyarakat, ternyata menunjukkan hasil yang didapat penyusun sungguh sangat mengejutkan, karena dari lokasi yang ditinjau yang merupakan jalan setapak diareal persawahan menuju ke poros jalan desa masih sangat jauh, sehingga apabila ada warga yang memanen hasi pertaniannya masih membutuhkan biaya lagi untuk mengoper hasil panennya selain biaya operasional lainnya. Hal ini sangat berpengaruh sekali terhadap hasil pendapatan warga Desa Donowarih.

Hasil wawancara dengan masyarakat ditanyakan persawa mengangkut hasil panennya, apa peran perangkat gun mendukung dalam proses penciptaan lingkungan yang mempunyai aksesibilitas yang tinggi, seberapa besar manfaat nantinya kalo dibangun jalan makadam yang menembus areal persawahan.

Untuk melakukan pelatihan, pengabdi bekerjasama dengan beberapa pihak, salah satunya adalah tim dari Dinas Pekerjaan Umum Kecamatan karangploso dan Staf khusus dari Kecamatan.

Pelatihan yang sudah dilaksanakan jauh sebelumnya, ternyata benar-benar sangat berpengaruh dalam merubah pola pikir masyaraka Desa Donowarih. Pelatihan yang berkaitan dengan lingkungan dan pentingnya aksesibilitas bag penunjang ekonomi kerakyatan ini telah diikuti oleh elemen masyarakat yang meliputi Karang Taruna dan

PKK telah menjadikan ajang diskusi yang menarik. Hal ini merupakan inovasi baru bagi masyarakat Desa Donowarih. Dampak langsung dari pelatihan adalah kesediaan dari warga yang tanahnya dibebaskan untuk menambah lebar jalan menuju ke areal persawahan. Sehingga pembangunan jalan makadam sepanjang

1.000 meter dan lebar 2,5 meter dengan mudah terlaksana. Ini merupakan jalan makadam pertama yang bisa menembus areal persawahan di tingkat Kecamatan Karangploso. 
Kegiatan survey untuk menentukan lokasi pembuatan konstruksi jalan makadam, ternyata bukan merupakan hal mudah bagi pengabdi dan pemegang keputusan di tingkat desa, karena ini menyangkut dampak secara langsung dan tidak langsung dari pemilik lahan pertanian yang akan ditingkatkan aksesibilitas menuju lahan pertaniannya melalui sosialisasi yang intensif dan terstruktur akhirnya didapatkan satu titik yang sangat memungkinkan untuk dilaksanakan peningkatan konstruksi jalan bagi masyarakat Desa Donowarih Kecamatan Karangploso.

Pembuatan atau peningkatan jalan dari jalan tanah/ setapak menjadi jalan makadam ini sepanjang 1.000 meter dengan lebar 2,5 meter dan selanjutnya diharapkan dengan dibangunnya jalan makadam ini akan ditingkatkan lagi menjadi lapis penetrasi sehingga bisa meningkatkan penghasilan dari masyarakat Desa Donowarih karena pengeluaran - pengeluaran yang selama ini terjadi bisa ditekan dengan adanya pembangunan jalan makadam ini.

\section{Pembahasa}

Kegiatan pengabdian ini belum ada parameterparameter dan indikator terukur yang menyatakan suatu keberhasilan dalam program ini. Meskipun begitu dalam program ini masih bisa dinyatakan secara kuantitatif untuk menyatakan keberhasilannya, karena dalam program ini telah dilampiri dengan beberapa dokumen yang mendukung tingkat keberhasilan program tersebut.

Menurut McClelland (1987), motif keberhasilan dapat ditingkatkan melalui pelatihan - pelatihan. Sebenarnya pelatihan itu dapat dilakukan oleh suatu lembaga maupun orang tua. Bahkan McClelland menyimpulkan besarnya peran seluruh komponen yang ada dimasyarakat untuk menyebarkan virus Need of Achievement ini. Orang tua dapat memulai menanamkan kesadaran terhadap lingkungan dan pembangunan melalui dongeng yang diceritakan kepada anak - anaknya yang menggambarkan suatu perjuangan dari si tokoh untuk merubah tatanan yang dimulai dari lingkungannya sendiri.
Berdasarkan riset aplikasi terbukti bahwa pelatihan atau sosialisasi yang terstruktur dapa meningkatkan motivasi dari masyarakat dalan usahanya untuk melakukan suatu perubah dolan lingkungannya. Pelatihan itu dirancang untuk meningkatkan pemahaman dan kesadaran masyarakat tentang pentingnya lingkungan yang bersih dan seha diwilayahnya masing - masing. Meskipun ini juga membutuhkan suatu proses dan waktu.

Berdasarkan hasil pendampingan ini dapat kembali dibuktikan bahwa pelatihan dan sosialisasi yang terstruktur dapat meningkatkan motivasi untuk berubah bagi masyarakat Desa Donowarih Kecamatan Karangploso Kabupaten Malang. Pelatihan in menggunakan model teknik learning by doing, sehingga masyarakat dapat menghayati karena mengalaminya sendiri. Nampak bahwa setelah mendapat pelatihan dan sosialisasi yang terstruktur masyarakat memiliki suatu keinginan atau rencan yang lebih baik untuk merubah pola hidup yang erkesan kurang perhatian terhadap lingkunganny menjadi lebih perhatian dengan lingkungan sekitarnya keberhasilan ini ternyata masih belum menyentuh masyarakat secara utuh di Desa Donowarih Kecamatan Karangploso, sehingga ke depan masih perlu dilakukan suatu pelatihan dan sosialisasi yang lebih terstruktur guna mencapai target yang diinginkan. Dalam sosialisasi ini juga diberikan materi tentang pentingnya pengelolaan dan pengolah suatu program kegiatan, sehingga diharapkan kedepan akan ada peningkatan pendapatan bagi sebagian masyarakat Desa Donowarih.

b. Saran untuk Masyarakat Desa Donowarih

Masyarakat diharapkan dapat menerapkan apa

\section{Kesimpulan}

Hasil dari aktifitas pengabdian pada masyarakat berupa assesment maupun pelatihan untuk masyarakat Desa Donowarih, dapat disimpulkan :

Masyarakat Desa Donowarih Kecamata Karangploso kurang mempunyai kesadaran terhadap lingkungannya, hal ini diperparah dengan kurang berperannya perangkat desa sebagai Modelling atau yang memberikan perlakuan - perlakuan yang dapat member contoh bagi Masyarakat Desa Donowarih.

2. Telah mulai tumbuh motivasi untuk merubah pola hidup dari yang kurang memperhatikan ngkungan, hal ini ditunjukkan dengan mulai embangunan jalan makadam dengan biaya dari masyarakat dan bantuan pemerintah daerah di Desa Donowarih Kecamatan Karangploso

3. Warga menyetujui untuk membuat konstruks jalan makadam yang melewati daerah pertanian diwilayah Desa Donowarih Kecamatan Karangploso, yang akan dikerjakan secara gotong royong dan padat karya.

2. Saran

Berdasarkan kesimpulan diatas, maka beberapa aran sebagai berikut :

\section{a. Saran untuk pihak Pemerintah Desa}

1. Diharapkan pihak Pemerintah Desa untuk dapat meneruskan kegiatan sosialisasi dan pelatihan-pelatihan ini dengan menciptakan suasana yang kondusif atau perlakuan pemberi support bagi warg peserta pelatihan, sehingga warga/ masyarakat menjadi lebih giat dalam menjaga dan melestarikan lingkungannya.

2. Pemerintah Desa diharap lebih peka dalam menangkap dan menerjemahkan aspirasi dari warganya sehingga tidak terjadi persoalan dibelakang hari. yang telah diperoleh dari hasil sosialisasi yang terstruktur dari pelatihan, sehingga masyarakat dapat lebih meningkatkan nilai-nilai kebersamaan diwilayah masing-masing.

\section{Daftar Pustaka}

A.A. Alamsyah, 2001, Rekayasa Jalan Raya. UMM Press., Malang.

Mc. Clelland, D. 1987. Memacu Masyarakat Berprestasi. ( Terj. ) Jakarta : Intermedia

D. Ruslan, 1999, Pengantar Teknik Jalan Raya Bagian III : Perencanaan Geometrik Jalan, Dit. Jen. Bina Marga Dept PU dan TI, Jakarta. 